\title{
Analysis of the molecular basis of Xanthomonas axonopodis pv. citri pathogenesis in Citrus limon
}

Florencia Siciliano

Instituto de Biología Molecular y Celular de Rosario

FByF, UNR, Suipacha 531, 2000

Rosario, Argentina

Tel: 03414356369

Fax: 0341 439-0465

E-mail: florisiciliano@yahoo.com.ar

\section{Pablo Torres}

Fundación Instituto Leloir

Av. Patricias Argentinas 435

Buenos Aires, Argentina

Tel/Fax: 0112387500

E-mail: PTorres@leloir.org.ar

\section{Lorena Sendín}

Estación Experimental Agroindustrial Obispo Columbres

Casilla $N^{\circ}$ 9, Las Talitas, 4101

Tucumán, Argentina

Tel: 03814276561

Fax: 03814276404

E-mail: lorenasendin@arnet.com.ar

\section{Carolina Bermejo}

Instituto de Biología Molecular y Celular de Rosario

FByF, UNR, Suipacha 531, 2000

Rosario, Argentina

Tel: 03414356369

Fax: 03414390465

E-mail: carober29@yahoo.com.ar

Paula Filippone

Estación Experimental Agroindustrial Obispo Columbres

Casilla $N^{\circ}$ 9, Las Talitas, 4101

Tucumán, Argentina

Tel: 03814276561

Fax: 03814276404

E-mail:mpaula@unt.edu.ar

\section{Gabriel Vellice}

Estación Experimental Agroindustrial Obispo Columbres Casilla No 9, Las Talitas, 4101

Tucumán, Argentina

Tel: 03814276561

Fax: 03814276404

E-mail: biotecnologia@eeaoc.org.ar

Jackie Ramallo

Estación Experimental Agroindustrial Obispo Columbres Casilla $N^{\circ}$ 9, Las Talitas, 4101

Tucumán, Argentina

Tel: 03814276561

Fax: 03814276404

E-mail: jramallo@eeaoc.org.ar

\section{Atilio Castagnaro}

Estación Experimental Agroindustrial Obispo Columbres Casilla $N^{\circ}$ 9, Las Talitas, 4101

Tucumán, Argentina

Tel: 03814276561

Fax: 03814276404

E-mail: atilio@eeaoc.org.ar 


\author{
Adrian Vojnov \\ Fundación Instituto Leloir \\ Av. Patricias Argentinas 435 \\ Buenos Aires, Argentina \\ Tel/Fax: 0112387500 \\ E-mail: avojnov@leloir.org.ar \\ María Rosa Marano* \\ Instituto de Biología Molecular y Celular de Rosario \\ FByF, UNR, Suipacha 531, 2000 \\ Rosario, Argentina \\ Tel: 03414356369 \\ Fax: 03414390465 \\ E-mail:mmarano@fbioyf.unr.edu.ar
}

Financial support: Agencia de Promoción Científica y Tecnológica (PICT-02 No: 08-10740).

Keywords: canker, DSF, extracellular polysaccharide, quorum sensing.

Abbreviations: DSF: diffusible signal factor

EPS: extracellular polysaccharide

Rpf: regulation of pathogenicity factors

Xac: Xanthomonas axonopodis pathovar citri

Xcc: Xanthomonas campestris pv. campestris

Xanthomonas axonopodis pathovar citri (Xac) causes bacterial citrus canker, a serious disease of most citrus species. Xanthomonas campestris pv. campestris (Xcc) is the causal agent of black rot disease in cruciferous plants. In Xcc, cell-cell signaling is mediated by diffusible signal factor (DSF). Synthesis of DSF depends on RpfB and RpfF. DSF perception and signal transduction have been suggested to involve a twocomponent system comprising RpfC and RpfG. It has been proposed that these proteins participate in a signal transduction system linking changes in the environment to the synthesis of DSF and the expression of virulence genes. Although the cluster of the rpf genes in Xac has synteny with the corresponding cluster in $X c c$, two genes (rpfH and rpfI) are absent in Xac. To investigate DSF-mediated regulation during Xac-Citrus limon interaction, we constructed two strains of Xac, one with a mutation in the $r p f F$ gene, leading to an inability to produce DSF, and one with a mutation in the $r p f C$ gene leading to an overproduction of DSF. These mutants also show decreased levels of extracellular cyclic $\beta$ (1,2)-glucans and decreased production of endoglucanase and protease extracellular enzymes. The Xac DSF-deficient $r p f F$ and the DSF-hyper producing $r p f C$ mutants are both severely compromised in their ability to cause canker symptoms in lemon leaves compared to the wild-type. Here we provide evidence that rpf genes in Xac are involved in controlling virulence factors mediated by DSF.

Citrus canker is an endemic disease of citrus in Argentina.
Invasion and colonization of the host mesophyll is accomplished through natural openings and plant tissue lesions (Graham et al. 2004). Most commercial citrus cultivars are moderately to highly susceptible to Xac. Thus, there is considerable need for a better understanding of the process of infection to pave the way for the development of biotechnology strategies that will support sustainable management of the disease.

Xcc is one of Xanthomonas species most extensively studied at the genetic level. The complete genome sequences of $X a c$ and $X c c$, revealed that the two bacteria have more than $80 \%$ of their genes in common and that their chromosomal gene order is largely conserved (da Silva et al. 2002). The ability of Xcc to elicit disease depends on several factors, including the synthesis of extracellular plant cell wall-degrading enzymes and the extracellular polysaccharide (EPS) xanthan (Tang et al. 1991). Production of these pathogenesis factors is regulated by a cluster of genes (A-I) called rpf (for regulation of pathogenicity factors) (Slater et al. 2000). Only two of these genes (rpfH and rpfI) are absent in Xac (da Silva et al. 2002). The predicted protein, $\mathrm{RpfH}$, is structurally related to the sensory input domain of RpfC (Slater et al. 2000). RpfI positively regulates the synthesis of proteases, endoglucanases and EPS in Xcc (Dow et al. 2000). The locus corresponding to rpfI in Xac is occupied by a truncated copy of an insertion sequence (da Silva et al. 2002). The absence of rpfH and rpfI in Xac may be consistent with the distinct modes of entry of the two bacteria, with $X c c$ accessing the leaf mainly via hydathodes at the leaf margin and subsequently colonizing the xylem

\footnotetext{
* Corresponding author
} 
vessels (Wallis et al. 1973) and Xac entering primarily through the stomates and colonizing the apoplasm of the fruit, leaf and stem tissue (Graham et al. 2004).

The major aim of this work is to identify genes involved in Xac pathogenicity, in particular, genes mediating cell-cell signaling. Our primary approach has been the isolation of additional mutants affected in the synthesis and perception of DSF. Such studies may provide a rational basis for the development of crop protection methods based on interference with intercellular signaling events.

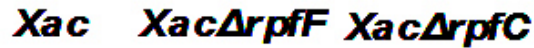

a

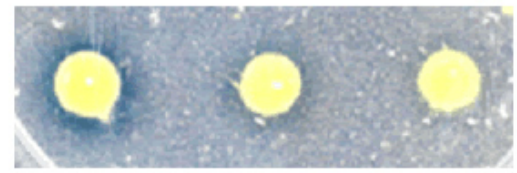

b
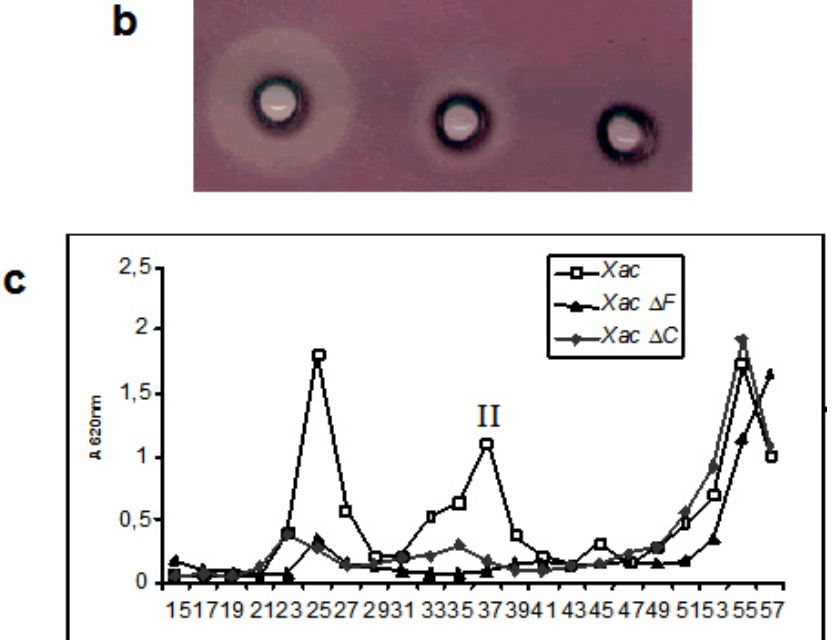

d

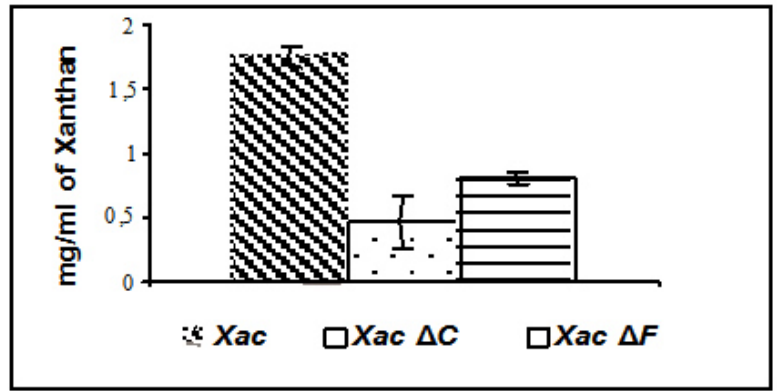

Figure 1. Phenotypic analysis of Xac rpfF and rpfC mutants.

(a) Protease production.

(b) Plate test for endoglucanase activity.

(c) Elution profile of LPS, I and extracellular cyclic $\beta$-(1,2)- glucan, II.

(d) Xanthan production.

\section{MATERIALS AND METHODS}

\section{Bacterial strains and culture conditions}

The wild-type (8004) and rpfF (8523) and rpfC (8557) mutant strains of Xcc were described previously (Tang et al. 1991; Slater et al. 2000). The wild-type strain of Xac was obtained from cankerous leaves of infected lemon trees in the province of Tucumán, Argentina. Xcc and Xac strains were cultured in peptone-yeast extract-malt extract (PYM) nutrient medium (Vojnov et al. 2001), supplemented with D-glucose at a final concentration of $2 \%(\mathrm{w} / \mathrm{v})$ at $28^{\circ} \mathrm{C}$. For growth on plates, PYM was solidified with $1.5 \%(\mathrm{w} / \mathrm{v})$ agar to make PYMA. L medium contained bactotryptone, $10 \mathrm{~g} / \mathrm{l}$; yeast extract, $5 \mathrm{~g} / \mathrm{l}$; sodium chloride, $5 \mathrm{~g} / \mathrm{l}$ and D-glucose, 1 g/l. E. coli strains were grown at $37^{\circ} \mathrm{C}$ in Luria-Bertani (LB) broth and on LB agar (Dow et al. 2003). Bacterial growth was measured in an spectrophotometer at $600 \mathrm{~nm}$. When required, the antibiotics, Rifampicin (Rif) and Kanamycin $(\mathrm{Km})$ were added to the growth media at concentrations of $10 \mu \mathrm{g} / \mathrm{ml}$ and $50 \mu \mathrm{g} / \mathrm{ml}$, respectively.

\section{Site-directed gene replacement of the Xanthomonas axonopodis pv. citri}

Genomic DNA from the Xac strain was extracted according to Chen and Kuo (1993). PCR products, from the region encoding the wild-type $X a c r p f F$ and $r p f C$ genes, were amplified using primers designed from Xac sequences available in GenBank (da Silva et al. 2002) and cloned into the pGEM-Teasy vector (Promega). A cassette containing a $\mathrm{Km}$ resistance gene was inserted in the $r p f F$ and $r p f C$ cleavage sites, generating deletions in the $r p f F$ and $r p f C$ gene. These constructs were digested and cloned into the suicide vector pSac (Quandt and Hynes, 1993) and transformed into wild-type Xac by electroporation. Transformed bacteria were selected on PYM media supplemented with $5 \%$ sucrose and $50 \mu \mathrm{g} / \mathrm{ml} \mathrm{Km}$. Disruption of the rpfF and $r p f C$ loci in the mutant strains was confirmed by PCR and Southern blot (data not shown).

\section{Bioassay of DSF extracted from culture supernatants}

DSF was extracted into ethyl acetate from culture supernatants of $X c c$ or Xac strains grown in PYM as described by Barber et al. (1997). The DSF bioassay is based on DSF's ability to restore endoglucanase production to Xcc rpfF mutants as described in Barber et al. (1997).

\section{Assays of extracellular enzymes and EPS}

For measurement of protease and endoglucanase activity, Xac strains were grown in PYM medium. Enzyme activity in cell-free culture supernatants were measured by radial diffusion assays into substrate-containing agar plates as described by Slater et al. (2000). For measurements of EPS production, strains were grown in PYM medium supplemented with 2\% (w/v) D-glucose for 24 hrs. EPS was precipitated from culture supernatants by ethanol, dried and weighed as described by Tang et al. (1991). Methods to isolate the cyclic glucan from culture supernatants, for sizeexclusion chromatography on BioGel $\mathrm{P} 4$, have been described previously (Vojnov et al. 2001). Bacterial cultures were washed and resuspended in water to a concentration of $10^{8} \mathrm{cfu} \mathrm{ml}^{-1}$. Samples of these suspensions $(50 \mu \mathrm{l})$ were spotted onto plates and allowed to dry before growth at $30^{\circ} \mathrm{C}$. Plates were stained when necessary as described in Tang et al. (1991). 
a
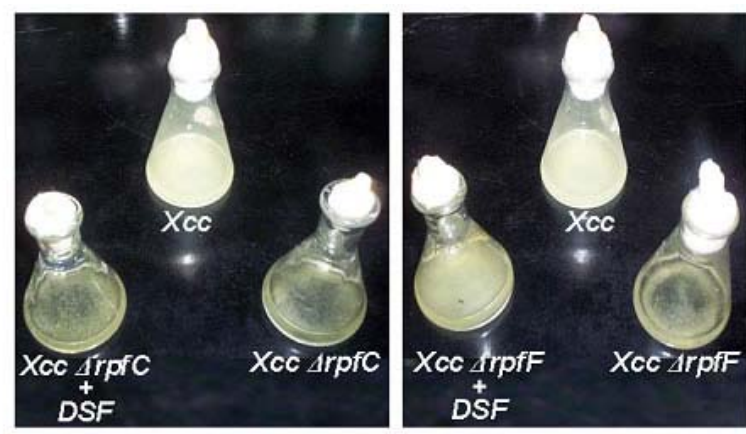

b

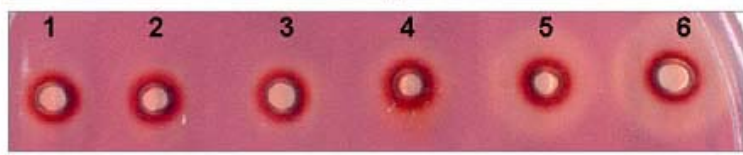

Figure 2. Role of DSF extracted from Xac $\Delta r p f C$ mutants.

(a) Strains of $X c c$ with mutations in rpfF and rpfC genes grow in an aggregated fashion in $\mathrm{L}$ medium, whereas the wild-type strain grows in a dispersed fashion. Addition of DSF from the Xac $\triangle r p f C$ mutant to rpfF strains, but not to rpfC strains of $X c c$, causes dispersed growth.

(b) Bioassay of DSF extracted from culture supernatants of Xac rpfF mutants (1), Xcc rpfF mutants(2), Xac wild-type (3), Xac rpfC mutant (4), Xcc wild-type (5) and Xcc rpfC strains (6).

\section{Plant preparation and measurement of bacterial growth in plant}

Citrus limon variety Eureka was grown in a greenhouse at a temperature of $18-25^{\circ} \mathrm{C}$. Xac and Xac mutants were grown in PYM media supplemented with the appropriate antibiotics at $28^{\circ} \mathrm{C}$ for $24 \mathrm{hrs}$. Cells were resuspended to a concentration of $10^{6} \mathrm{cfu} \mathrm{ml}^{-1}$. Xac strains were assayed for pathogenicity by inoculation of bacteria into the lamina of mature and young lemon leaves using three different procedures, namely pressure infiltrating with a $2 \mathrm{ml}$ syringe without a needle, nicking the underside of the leaves with a razor blade followed by spraying, and spraying without nicking. The last method mimics the natural Xac infection process, in which bacteria enter to the leaf through openings in the leaf (via stomata), followed by colonization of the apoplasm. Inoculated plants were maintained for 35 days in a growth cabinet, with temperatures ranging from $25-28^{\circ} \mathrm{C}$, high humidity, a photoperiod of 16 hrs light, and a light intensity of 150 a $200 \mu \mathrm{E} / \mathrm{sm}^{2}$. Disease progression was monitored phenotypically and through analysis of bacterial growth curves (Siciliano et al. 2005).

\section{RESULTS AND DISCUSSION}

\section{Isolation of Xanthomonas axonopodis pv. citri mutants with altered levels of DSF}

The mutant strains $\triangle r p f F$ and $\triangle r p f C$ of $X a c$ were screened for protease and endoglucanase activities, as well as for levels of cyclic $\beta$-(1,2)- glucan and xanthan. The proteolytic activity was scored by detecting degradation of milk proteins, seen as a zone of clearing around the colonies. As shown in Figure 1a, the halo around the colony of the $r p f F$ and $r p f C$ mutants is reduced compared with the wild-type Xac strain. The activities of endoglucanase, an enzyme involved in plant cell wall degradation, was measured by a plate diffusion assay, where the zones of clearing indicate degradation of carboxymethylcellulose (CMC). Similar to protease activity, endoglucanase activity was found to be reduced in both $r p f F$ and $r p f C$ mutants (Figure 1b).

As shown in Figure 1c and Figure 1d, cyclic $\beta$-(1,2)glucan and xanthan in the Xac $\Delta r p f F$ and $\triangle r p f C$ mutants are reduced compared to wild-type Xac. Based on these results and given that these pathogenicity factors are induced by DSF, we can infer that DSF levels are altered in the $X a c \Delta r p f F$ and $\triangle r p f C$ mutants.

\section{Xac DSF reverses the phenotype of Xcc rpfF mutants}

Strains of $X c c$ carrying mutations in the $r p f F$ and $r p f C$ genes grew as matrix-enclosed aggregates in $\mathrm{L}$ medium, whereas the wild-type Xcc strain grew in a dispersed fashion. (Dow et al. 2003). We investigated the behavior of the Xcc $\triangle r p f F$ (8523) and $\triangle r p f C$ (8557) mutants in the presence of DSF extracts taken from the Xac $\Delta r p f C$ mutant. As shown in Figure 2a, wild-type Xcc grows in a dispersed fashion, but $X c c r p f F$ and $r p f C$ mutants do not. Addition of DSF extracted from the Xac $\triangle r p f C$ mutant reverses the phenotype of mutant 8523, but not mutant 8557. Based on these findings, we conclude that the Xac $\triangle r p f C$ mutant produces DSF, which induces bacteria to grow in a dispersed manner, and that DSF from $X c c$ and Xac likely share structural similarities.

To confirm that $X a c$ is able to produce DSF, we analyzed DSF extracted from wild-type and Xac mutants using the DSF bioassay developed by Barber et al. (1997), which relies on the restoration of endoglucanase activity to an $r p f F$ mutant strain of Xcc. Ethyl acetate extracts of culture supernatants from mutant and wild type strains were assayed for DSF activity. As expected the extracts of the Xac $\triangle r p f C$ mutants show bigger halos compared with the wild-type, while the $r p f F$ strain extracts show no halos indicative of CMC degradation (Figure 2b). Extracts from $X c c$ DSF-hyper producing $r p f C$ and DSF-non-producing $r p f F$ mutant strains were used as controls (Figure 2b).

\section{Reduction of virulence on lemon leaves is preferentially associated with mutation of the rpfC gene in Xac}

To test whether the mutations in the $r p f F$ and $r p f C$ genes of Xac affect general fitness in plant, bacteria suspensions were inoculated at a concentration of $10^{6} \mathrm{cfu} \mathrm{ml}^{-1}$, followed by measurements of bacterial growth and observation of canker symptoms. Figure 3 shows symptoms on lemon leaves 35 days post-infection (d.p.i.) using the methods 


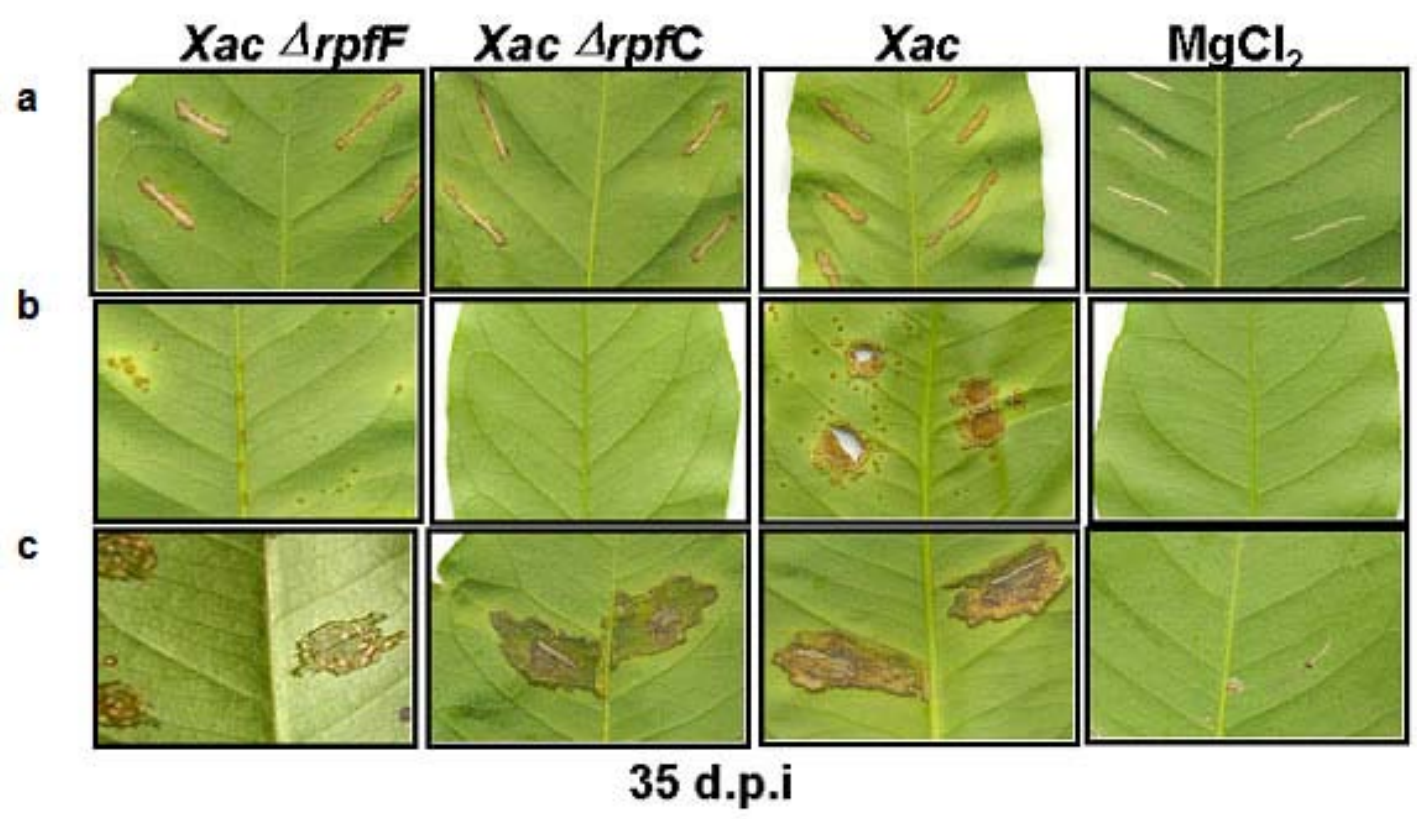

Figure 3. Macroscopic symptoms (canker) in Citrus limon variety Eureka. Each strain was inoculated into three different leaves. Infected plants were observed for disease symptoms (formation of cankers) over the course of 35 days under optimal temperature and humidity.

(a) Inoculation by nick and spray

(b) spray

(c) pressure infiltration

described above (nick and spray, A; spray alone, B; and pressure infiltration, C) with Xac $\triangle r p f F$ and $\triangle r p f C$ mutants and wild-type Xac. Although both mutants show reduced pathogenicity compared with wild-type, the DSF-hyper producing mutant $(r p f C)$ is more severely compromised in its ability to cause canker disease in citrus. These results are most clearly evident with the spray inoculation method (B). Plants inoculated with $\mathrm{MgCl}_{2}$ show no disease symptoms.

Further study of DSF `role in the plant inmune response and other regulatory mechanisms should advance our understanding of the adaptation of bacteria to parasitic life within plants and may allow us to develop tools to control Xanthomonas infection that function across plant species.

\section{ACKNOWLEDGMENTS}

We thank Dr. Marcelo A. Dankert for his continuous support.

Atilio Castagnaro, María Rosa Marano and Adrián Vojnov are members of the Career Investigator of the Consejo Nacional de Investigaciones Científicas y Técnicas.

\section{REFERENCES}

BARBER, C.E.; TANG, J.-L.; FENG, J.-X.; PAN, M.Q.; WILSON, T.J.G.; SLATER, H.; DOW, M.J.; WILLIAMS, P. and DANIELS, M.J. A novel regulatory system required for pathogenicity of Xanthomonas campestris is mediated by a small diffusible signal molecule. Molecular microbiology, May 1997, vol. 24, no. 3, p. 555-566.

CHEN, W.-P. and KUO, T.-T. A simple and rapid method for the preparation of Gram-negative bacterial genomic DNA. Nucleic Acids Research, May 1993, vol. 21, no. 9, p. 2260.

DA SILVA, A.C.R.; FERRO, J.A.; REINACH, F.C.; FARAH, C.S.; FURLAN, L.R.; QUAGGIO, R.B.; MONTEIRO-VITORELLO, C.B.; VAN SLUYS, M.A.; ALMEIDA, N.F.; ALVES, L.M.C.; DO AMARAL, A.M.; BERTOLINI, M.C.; CAMARGO, L.E.A.; CAMAROTTE, G.; CANNAVAN, F.; CARDOZO, J.; CHAMBERGO, F.; CIAPINA, L.P.; CICARELLI, R.M.B.; COUTINHO, L.L.; CURSINO-SANTOS, J.R.; EL-DORRY, H.; FARIA, J.B.; FERREIRA, A.J.S.; FERREIRA, R.C.C.; FERRO, M.I.T.; FORMIGHIERI, E.F.; FRANCO, M.C.; GREGGIO, C.C.; GRUBER, A.; KATSUYAMA, A.M.; KISHI, L.T.; LEITE, R.P.; LEMOS, E.G.M.; LEMOS, M.V.F.; LOCALI, E.C.; MACHADO, M.A.; MADEIRA, A.M.B.N.; MARTINEZROSSI, N.M.; MARTINS, E.C.; MEIDANIS, J.; MENCK, C.F.M.; MIYAKI, C.Y.; MOON, D.H.; MOREIRA, L.M.; NOVO, M.T.M.; OKURA, V.K.; OLIVEIRA, M.C.; OLIVEIRA, V.R.; PEREIRA, H.A.; ROSSI, A.; SENA, J.A.D.; SILVA, C.; DE SOUZA, R.F.; SPINOLA, L.A.F.; TAKITA, M.A.; TAMURA, R.E.; TEIXEIRA, E.C.; TEZZA, R.I.D.; TRINDADE DOS SANTOS, M.; TRUFFI, 
D.; TSAI, S.M.; WHITE, F.F.; SETUBAL, J.C. and KITAJIMA, J.P. Comparison of the genomes of two Xanthomonas pathogens with differing host specificities. Nature, May 2002, vol. 417, no. 6887, p. 459-463.

DOW, M.J.; CROSSMAN, L.; FINDLAY, K.; HE, Y.-Q.; FENG, J.-X. and TANG, J.-L. Biofilm dispersal in Xanthomonas campestris is controlled by cell-cell signaling and is required for full virulence to plants. Proceedings of the National Academy of Sciences of the United States of America, September 2003, vol. 100, no. 19, p. 10995-11000.

DOW, M.J.; FENG, J.-X.; BARBER, C.E.; TANG, J.-L. and DANIELS, M.L.J. Novel genes involved in the regulation of pathogenicity factor production within the rpf gene cluster of Xanthomonas campestris. Microbiology, April 2000, vol. 146, no. 4, p. 885-891.

GRAHAM, J.H.; GOTTWALD, T.R.; CUBERO, J. and ACHOR, D.S. Xanthomonas axonopodis pv. citri: factors affecting successful eradication of citrus canker. Molecular Plant Pathology, January 2004, vol. 5, no. 1, p. 1-15.

QUANDT, J. and HYNES, M.F. Versatile suicide vectors which allow direct selection for gene replacement in Gramnegative bacteria. Gene, May 1993, vol. 127, no. 1, p. 1521.

SICILIANO, F.; TORRES, P.; SENDÍN, L.; BERMEJO, C.; FILIPPONE, P.; VELLICE, G.; RAMALLO, J.; CASTAGNARO, A.; VOJNOV, A. and MARANO, M.R. Estudio de las bases moleculares de la patogénesis de Xanthomonas axonopodis pv. citri en Citrus limon. In: BAIRESBIOTEC 2005. (6 ${ }^{\circ}$, 7th-10th June, 2005, Buenos Aires, Argentina). Abstracts, 2005. p. 349-350.

SLATER, H.; ALVAREZ-MORALES, A.; BARBER, C.E.; DANIELS, M.J. and DOW, M.J. A two-component system involving an HD-GYP domain protein links cellcell signalling to pathogenicity gene expression in Xanthomonas campestris. Molecular Microbiology, December 2000, vol. 38, no. 5, p. 986-1003.

TANG, J.-L.; LIU, Y.-N.; BARBER, C.E.; DOW, M.J.; WOOTTON, J.C. and DANIELS, M.J. Genetic and molecular analysis of a cluster of rpf genes involved in positive regulation of synthesis of extracellular enzymes and polysaccharide in Xanthomonas campestris pathovar campestris. Molecular and General Genetics, May 1991, vol. 226, no. 3, p. 409-417.

VOJNOV, A.A.; SLATER, H.; NEWMAN, M.-A.; DANIELS, M.J. and DOW, M.J. Regulation of the synthesis of cyclic glucan in Xanthomonas campestris by a diffusible signal molecule. Archives of Microbiology, December 2001, vol. 176, no. 6, p. 415-420.

WALLIS, F.M.; RIJKENBERG, F.H.J.; JOUBERT, J.J.; MARTIN, M.M. Ultrastructural histopathology of cabbage leaves infected with Xanthomonas campestris.
Physiological Plant Pathology, 1973, vol. 3, no. 3, p. 371378. 